\title{
FROM BASTIONS OF JUSTICE TO SITES OF ADVENTURE
}

\author{
Grete Swensen
}

\begin{abstract}
A continuous discussion of which perspectives to include and which to exclude characterises the definition of cultural heritage. After Norway's new Prison Act had been introduced in 1857, the foremost architects in the country were engaged when the decision was made to build a series of regional prisons. Today some of these former bastions of justice need to be accorded new functions. The discussion here is based on an examination of two former prisons that have been turned into cultural institutions. It is a contemporary study primarily based on observations and photographic documentation, supplemented by information from local historical literature and informal conversations (interviews). The research questions are: What processes are put into effect if buildings erected to ensure punishment are regarded as cultural heritage, and what processes of selection of relevant stories take place? Focus is put on how and why certain aspects of the past are highlighted and others are silenced, and several factors are involved here. Ignoring certain elements can be a way to protect individuals from exposure and recognition on purely ethical grounds, but it can also be a way of excluding historical events that do not correspond very well with the new cultural profile.
\end{abstract}

Keywords: culture industries, dissonant heritage, heritage tourism, historical monuments, memory sites, prison architecture

\section{INTRODUCTION}

A common mantra in present-day heritage management is preservation through adaptive reuse, and a sub-chapter in the latest White Paper on cultural heritage policy is titled 'Protection, Use and Development' (Meld. St. 35: 41). Yet, what happens to buildings when they have to be adjusted to meet today's needs? Not only is there a series of building regulations to be adhered to, but changes and adjustments have to be made to accommodate the new functions. As new features are added, former connotations disappear. Some of the prison buildings erected in the late nineteenth century were based on drawings by some of the leading architects of the period, and as former monuments of justice with high architectural value a number of these buildings are listed. Cultural and recreational activities in various forms are functions well suited for this type 
of buildings. Culture is used as a strategy to rejuvenate city centres and is an instrument for economic development (Throsby 2001; Freestone \& Gibson 2006; Evans 2009). In these processes heritage is assigned a new role, and old monumental buildings requiring a new use can serve new cultural purposes. This is an international trend, and examples of old prison buildings adapted for new uses can be found in several cities (see, e. g., Taylor 1994; Flynn 2011).

The purpose of this paper is to look more closely into how the prison history is described and mediated in two former prison buildings in Norway. The motivations behind the present use of the buildings are various, ranging from the intention to stimulate new local cultural arenas and increase insight into local cultural history, to serving solely commercial ends. The prisons in focus belong to a group that were erected as a result of the Prison Act of 1857, after which it was decided that 56 regional prisons should be built across the country (Kjus 2010). It was necessary to limit the analysis to a smaller group of buildings and therefore the ones included in the study have a common feature: they went out of active use as prisons when reforms were introduced in the criminal justice system. They were either sold to private owners or taken over by the municipality.

The two former prisons that are examined here are situated in medium-sized towns where they have been converted into cultural centres. The article is a contemporary study based primarily on observations and photographic documentation. I employ a critical visual approach, whereby particular attention is paid to the social conditions and effects of visual objects (Rose 2007 [2001]: 12). These sources are supplemented by information from local historical literature and informal conversations (interviews) with people involved in the present operation of cultural institutions. The following questions are raised: Which processes are put into effect when buildings erected to ensure punishment are regarded as cultural heritage? Which processes of selection (inclusion/exclusion) are taking place in terms of relevant stories? Focus is put on how and why certain aspects of the past are highlighted whereas others are silenced.

\section{RESEARCH FRAMEWORK}

Buildings can be studied from a series of angles. Here they will be read in terms of social relations. Their forms provide answers to questions of power, order, classification and function (Foucault 1991 [1977]; Markus 1993). Where prisons are concerned, the purposes of control and discipline are underlined in the choice of architectural form and layout. It is important to stress, however, that this is not a study of the historic buildings as such, but rather a study of the process of turning a particular class of buildings into cultural heritage (see 
also Swensen 2012). Cultural heritage is here defined as 'contemporary use of the past' (Graham \& Ashworth \& Tunbridge 2000: 2). In the process of defining the assets worthy of safeguarding as cultural heritage for the future, a series of conscious or unconscious decisions are made. In the process, certain features can be highlighted and others erased. Rather than relating to history as such, heritage, according to Kirschenblatt-Gimblett, can be viewed as a mode of cultural production that uses the past actively to produce something new, being regarded as 'a mode of cultural production (that) adds value to the outmoded by making it into an exhibition of itself' (Kirschenblatt-Gimblett 2012: 199). Choices involving inclusion and exclusion of relevant history cause disagreement in a number of heritage cases, or elements of what Tunbridge and Ashworth (1996) have named 'dissonant heritage' - a concept that stresses a lack of agreement and consistency. Some locations have been difficult to recognise as part of a national or local community's heritage because they represent particular painful or shameful episodes. Prisons belong to a type of heritage that has been labelled 'difficult heritage' (Logan \& Reeves 2009) or 'contested heritage' (Flynn 2011) and encompasses massacre and genocide sites and prisoner-of-war sites. Civil and political prisons and lunatic asylums are also included (Tomlinson 1984; Edginton 1997; Al-Hosany \& Elkadi 2002; Strange \& Kempa 2003; Rosenthal 2008; Stone \& Sharpley 2008; Flynn 2011). Sharon Macdonald writes about 'unsettling memories', when she refers to the controversy over turning a major Nazi building into a shopping centre (Macdonald 2009). In the interpretation of heritage sites it is important to determine the aspects of the past that are being ignored or poorly represented.

Urry (1990) was among the first researchers to spot the trend towards a market where a combination of tourism and heritage manifested itself. He suggested that a transformation in production and consumption patterns had resulted in a convergence between tourism and heritage activities. The tourism market became more diversified. More tourists turned away from package holidays to more sophisticated breaks, in which exclusivity, differentiation and unique personal experiences became the norms. The Framework Convention on the Value of Cultural Heritage for Society (the Faro Convention) can be seen as a major step to promote a wider understanding of heritage and its relationship to community, society and nation, and it is a result of efforts laid down during recent years to reach an agreement around a more inclusive heritage notion (Council of Europe 2008: 7). The text presents heritage both as a resource for human development, the enhancement of cultural diversity and the promotion of intercultural dialogue, and as part of an economic development model based on the principles of sustainable resource use. A range of places, sites and institutions are connected to painful periods in history. When Logan and Reeves (2009) raise the question what drives the growing world interest 
in places of past pain, shame, humiliation and the macabre, they base it on the observation that 'atrocity tourism' is booming. This point led Ashworth and Hartmann (2005) to revisit and take a closer look at the management of atrocity sites for tourism. The simple fact that the number of tourists who chose to visit sites and memorials of atrocity is increasing, led them to direct attention to the motives that lie behind this trend. The main reasons that they indicate are the curiosity argument, the empathy argument and the horror argument (Ashworth \& Hartmann 2005).

A useful concept for a further analysis of the creation of meaning and mediation of history, which takes place when buildings step into new contexts, is 'silence'. Winter describes silence as 'a socially constructed space in which and about which subjects and words normally used in everyday life are not spoken' (Winter 2010: 4). The circle around the silent space is drawn by a group of people that at a given time find it appropriate to distinguish between what can be said and the unmentionable. "Such people codify and enforce norms which reinforce the injunction against breaking into the inner space of the circle of silence" (Winter 2010: 4). Perspectives around 'the silent' have been used in discussions concerning atrocities and ethnic cleansing, to which larger social and ethnic groups have been exposed, chapters of history that fairly recently have given rise to new memorial museums and sites that aim to 'fight the forgetful future', as Paul Williams has put it (2007: 181; see also Deacon 2004). The present article argues whether silencing is relevant as to how the history of prisons is mediated.

The selection of cultural heritage for protection is built on a series of arguments. In the further presentation of processes that take place when institutions built for punishment are redefined to become cultural institutions, special attention will be paid to the visual dimension. Visualisation, aestheticisation and 'the power of the eye' are dimensions that have been widely discussed in connection with modernity, post-modernity and urbanism. It has been pointed out that a marked border has gradually been formed between the visual and its material context, which has resulted in the abstraction of the observable world (Gregory 1994: 404; Lefebvre 1991 [1974]: 361ff.; Mordue 2010: 172ff.; Sturken \& Cartwright 2009 [2001]: 460).

Cultural practices like visual representations both depend on and produce social inclusions and exclusions, and a critical account needs to address both those practices and their cultural meanings and effects. (Rose 2007: 12)

Related topics are discussed by Sarah Pink (2009) when she reflects on what is involved in sensory ethnography. These dimensions are relevant in the present 
context and will be discussed in relation to the history of prisons as they are redefined as cultural heritage. An outside observer would weigh different elements of history differently from people with local insight or lived experience.

\section{REUSE AND REDEFINE: THE CULTURAL BIOGRAPHY OF TWO OLD PRISON BUILDINGS}

In the following, the history of each prison is briefly presented from the point of view of a cultural biographical approach. This approach was first presented by social anthropologist Kopytoff (1986: 64) and later on elaborated in a study of a group of historic buildings (Swensen 1997). The biographical approach constitutes a description of the different phases through which a building passes (see also Brand 1994). The first phase of a building's biography is when it is newly built and fulfils its function adequately. Gradually it becomes outdated and needs to be adjusted and modernised to be able to serve its intended purpose (phase 2). Some buildings are subsequently considered unsuitable for their intended purpose and gradually become empty (phase 3). Many buildings are taken down in this phase, but some are left unattended and derelict. As time passes, a few of these old buildings change character. Although they are still generally

Figure 1. The 56 regional prisons established in Norway after 1857. The map, which is based on historical information provided by Kjus (2010), illustrates where the 56 regional prisons were established. The two prisons examined in the study are highlighted. Map production: NIKU.

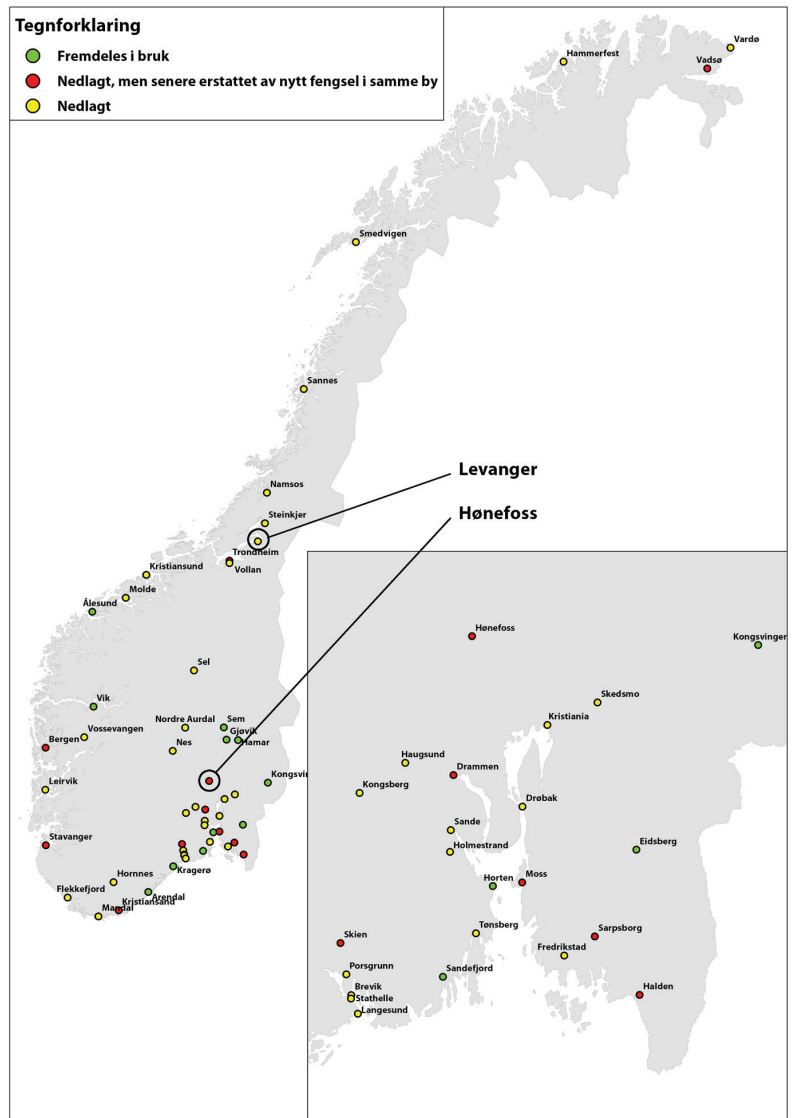


considered useless by the majority, experts and idealists might assess the cultural historic value of such buildings by means of the criteria used by antiquarians, such as representativity, uniqueness, outstanding architecture, symbolic or social value, etc. Buildings enter a stage where they are considered to possess a long-lasting value as cultural heritage (phase 4). The biographical approach will now be used to describe two former prisons currently in use as cultural institutions.

The old Hønefoss prison (Stiftelsen Fengselet) is situated in the centre of Hønefoss, a small town approximately $60 \mathrm{~km}$ north of Oslo. It was built in 1862 and was one of the three prisons established in Buskerud County (phase 1). All three were based on the design of the same architect, Henrik Thrap-Meyer. When the Hønefoss prison opened in 1864, it held 14 cells, including two at the police disposal. It was a complex built entirely of wood and consisted of several buildings, exercise yards, and a large yard and garden enclosed by a wooden fence. The front building occupied one and a half storeys and the main prison building, in which the cells were situated, consisted of two full storeys. The southern part of the front building housed the courtroom and the rest of the space comprised a large flat for the caretaker. An outhouse in the northern part of the complex also held a cell for drunkards (Drange 2001) (phase 2). In 1999, the building was closed down as a prison and sold off cheaply to the municipality. For a while, the prison complex was supposed to be sold and new buildings erected in the garden (phase 3). The gradual decay of the impressive building complex, however, worried people with an interest in local history and the cultural heritage management at the regional level. They received unexpected help from the regional bank manager, who shared their concern that one of the town's remarkable buildings could be lost unless drastic action was taken. He managed to convince the regional bank to step in. At this stage cultural heritage management designated the complex for preservation through the Norwegian Cultural Heritage Act, and the restoration work started (phase 4). When Hønefoss celebrated its 150 th jubilee in 2002, the regional bank decided to gift the building to the people for use as a cultural institution.

The old Levanger prison (Galleri Fenka) was built in brick in 1897, from a technical drawing by recognised architects Schirmer and von Hanno (phase 1) (Schirmer \& von Hanno 1859; Hamran 1962). It was erected on the site of an old prison that was burnt down in one of the fires that struck the town of Levanger. A few years later (1900), a fire station was built on a neighbouring site. The prison had four cells on the ground floor, a caretaker's flat and a drunkards' cell in the basement. The courtroom was on the first floor, which also functioned as a municipal council hall until 1956 (phase 2). The building closed as a prison that same year, after which it was used as the town library. When the library 

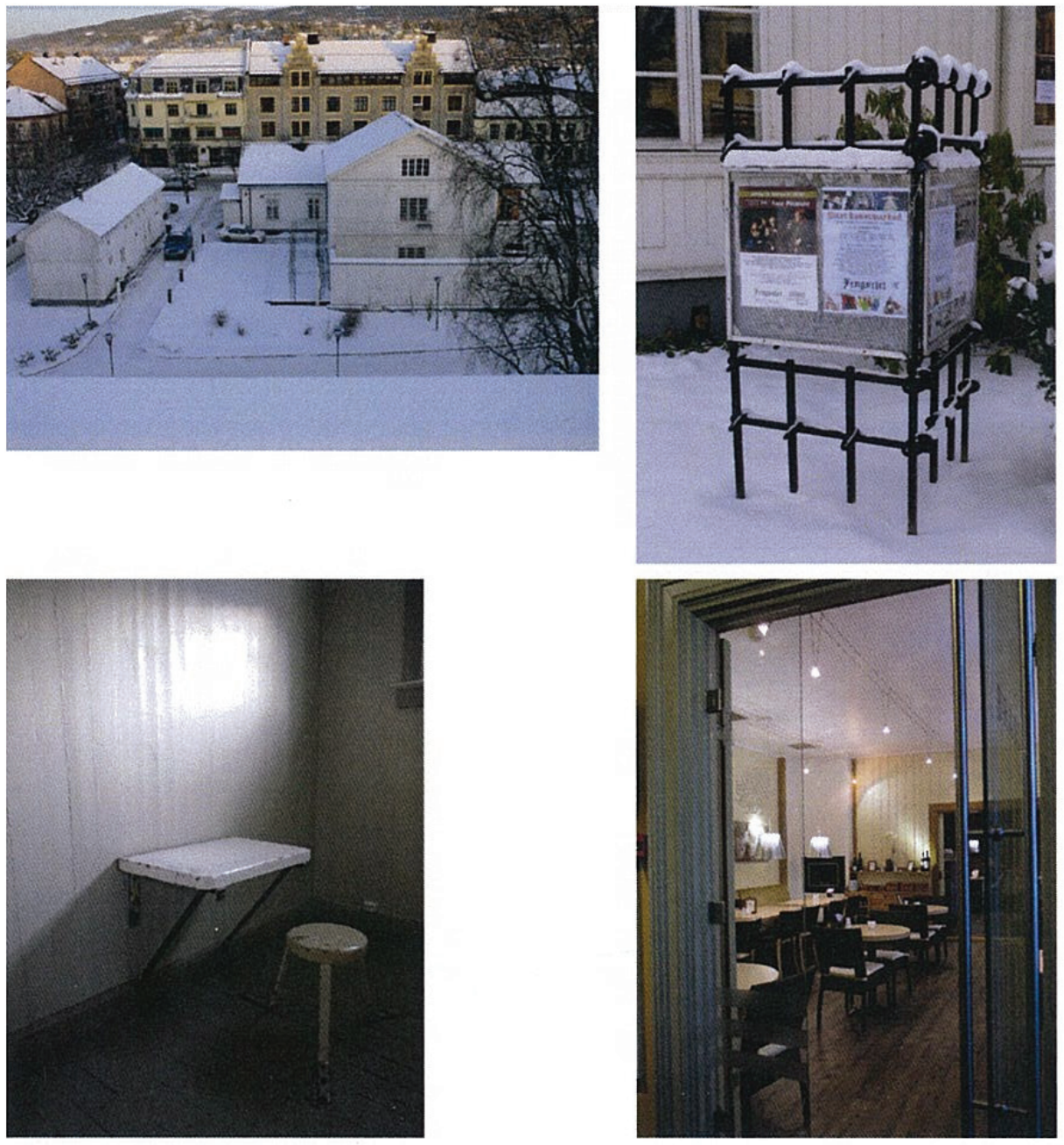

Figure 2. Stiftelsen Fengselet, Hønefoss. The photos show clockwise an overview of the former prison complex including the yards, which are now surrounded by the town park, a specially designed notice board, a restaurant, and a restored prison cell. Photos: NIKU.

moved out in 1987, the building was used as a youth club for a while, but when all the activities terminated in 1999, it fell in disuse (phase 3 ). The building was mentioned in the county cultural heritage preservation plan in 1988. It was included in the town regulation plan from 1993 and gained status as a listed building according to the Norwegian Plan and Building Act. The planners in the municipality were worried about the increasing decay of the building and 
estimated in 2003 that it would cost more than 2.1 million Norwegian kroner (262,500 Euros) to rehabilitate it. Limited municipal resources mean, however, that this sort of need is not given priority. When two glass artists showed interest in turning the old prison into an art gallery, they were offered the prison for a reasonable sum (phase 4). Apart from a minor grant, the rehabilitation, which lasted for two years, has been financed by the artists. The new gallery opened in 2008 (Fenka 2008; Levanger Historielag 2011). As pointed out by other researchers, it is not unusual for artists to make use of such sites for their exhibitions (DeSilvey 2010).
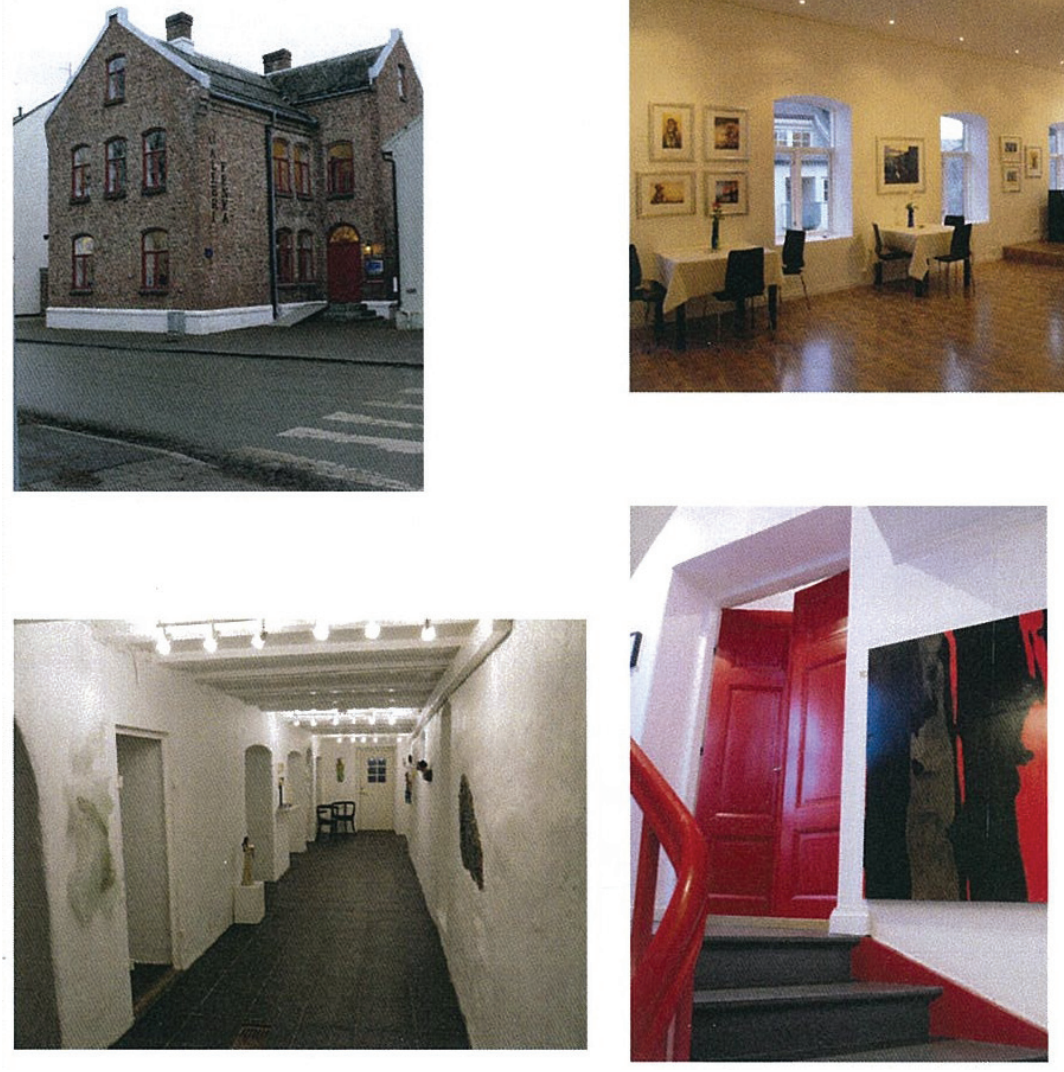

Figure 3. Galleri Fenka, Levanger. The photos show clockwise the exterior of Galleri Fenka in Levanger, the former court room on the first floor, the stairway on the first floor and the former cell for drunkards in the basement. Photos: NIKU. 


\section{DISCUSSION: VARIOUS WAYS OF MEDIATING DIFFICULT HISTORY}

In the light of the cultural biography of the two former prisons, I will now proceed to discuss the processes of selection that are taking place when buildings enter into phase 4 . What happens when former prison buildings are being transformed to cultural heritage is exemplified by processes of inclusion and exclusion of relevant stories. Independent of the degree of formalised protection, the future use is based on some other criteria as well, such as 'finding an argument for further life', that is, finding alternative uses that do not conflict with restrictions imposed by protection orders.

A building's history can be used in various ways as a platform to create new images. Following Schudson (1995; cited in Benton \& Cecil 2010) and his four elements of memory production (distancing, instrumentality, narration, cognition), I will show how the two cultural institutions apply distancing, instrumentality and narration to build a profile. Similarities occur in the way that fragments from the old buildings are lifted out, aestheticised and redefined as symbols.

Distancing is a way of creating forms of adventure and it contrasts the original form and function with those of today. It can be achieved both through playing with forms in the exterior and interior and by making use of the way in which the functions have changed. Stiftelsen Fengslet in Hønefoss offers several relevant examples. The information board outside the main entrance conjures up associations as a functional sculpture constructed of iron bars like those used in front of the windows of the prison cells. Another example is the restaurant. The former caretaker's flat has been turned into an attractive restaurant, Brasseriet. The name signifies that this is a modern, urban place in which to eat out with friends. The door to the restaurant functions in the same way. Immediately after entering the original main door to Fengselet, one's attention is drawn to the right, where Brasseriet can be seen behind a double glass door. Here the guests sit inside the restaurant in an attractive and modern interior. There are no direct references to the original function of the building at this stage. But what is gained is a contrasting effect achieved through simplification and aestheticisation: a comparison of the delicious and tasteful (aromatic, atmospheric, clean) with a past that can be perceived as nasty and revolting (dirty, smelly, immoral). How cultural remembrance might be practised and performed in a place confronted with its own threatening cessation has also interested others (see, e.g., DeSilvey 2010: 496). The factor with the most distancing effect in Galleri Fenka in Levanger is the distinctive, bright colours, such as white and red on the windows, doors, and staircases, which contrast with the solid brick walls and the heavy iron gate leading to the 
former prison yard. It succeeds in creating a happy and inviting atmosphere. The simple and attractive furniture on the second floor enhances the appearance of the large hall, which is now used as a gallery as well as a conference venue and concert-hall.

Instrumentalisation is used in a positive sense here, to describe how these buildings can be used to provide new cultural meeting places or to house different commercial businesses like hotels and restaurants. In both Hønefoss and Levanger there are examples showing the use of original building elements as key symbols. The heavy cell doors with their locks and hatches have a particularly strong mediating effect. In Galleri Fenka only some of the original cell doors have survived, and some of the locks are missing. The doors have been rejuvenated, however, and stand out in contrast to the whitewashed and newly chalked walls, black-tiled floors and red mouldings. Some windows still have the iron bars intact. The former cells are today filled with art. Stiftelsen Fengselet occupies a full block in the town centre, and the area functions as a busy park that people pass through on their way through town. After the property changed ownership, the building complex was designated for preservation through the Norwegian Cultural Heritage Act and now any maintenance or rehabilitation work has to be done in consultation with the Norwegian Cultural Heritage Directorate (Riksantikvaren). As it is a listed building, originality and authenticity play a central role. The tendencies towards aestheticisation described earlier represent a pitfall in this respect. Since authenticity as practised in restoration work is restricted to issues concerning the material structure, images of darkness, overcrowding, and smell are not - for obvious reasons - included. Museums, however, can work with a broader scale of instruments to mediate a message. The building's exterior was repainted in white and grey as early as 1913, but at present restoration work is being done to recover the original shade of the yellow exterior. Restoration work inside has ensured that the cell corridors have retained their original stark and hostile character intact. Recently a cell has been reconstructed after the original pattern, the bed and the desk locked to the wall to retain authenticity. A culture director manages Fengselet today, and its various cultural activities, such as art exhibitions and concerts, as well as the restaurant, suggest that it represents an important institution. The courtroom with its fixed decorative banister gives special character to its use as an intimate concert hall and for larger concerts in the summer one of the outside exercise yards is used. Former cells function as exhibition halls and workshops for various artists.

Narrative styling describes activities that in more or less eclectic ways make use of a selection of facts to create new stories. History functions to attract attention and create excitement. Name-giving to the new functions and activities 
exemplifies ways of using history for various forms of profit. The names are emptied of their original content and supplied with new and positive associations, including humour. In Hønefoss an annual concert named Jailhouse Rock draws at least 400 visitors at each performance. The park called the Prison Garden is kept in excellent condition by the local Garden Society, and a fund named Celledeling (Cell Sharing) has been established to encourage young musical talents in the district. Elements of the prison's history are presented in a brochure available via the Internet, and there is a chapter about the prison in the town history published for the town's jubilee. The slogan used by the owners of Galleri Fenka in their information brochures also plays on the word fengslende, which refers to imprisonment as well as to something striking or catching.

A fourth dimension, recognition and empathy, has not been discussed in relation to this presentation, because it is not present to any real degree in the two cases under discussion. It is, however, known elsewhere, where artists have cooperated with cultural institutions to consciously mediate the sense of alienation that imprisonment confers (see Swensen 2013). One should ask, however, whether recognition and empathy should be present. None of the sites tell the story of any of the many former prisoners or their guards. Are the new custodians obliged to tell their stories, the consequences of their crimes and their punishment? Prisons would seem to be prime settings for local and public history. It is open for discussion whether our two case studies, which prioritise 'set pieces' and 'digestible' narratives, are wilfully complicit in 'memory distortion' (Schacter 1995).

Pragmatism no doubt strongly affects the way in which the buildings are presented: thorough discussions about what meanings and values to protect have to step aside for considerations regarding the functions that the buildings have potential to fill. They share this potential with a number of other buildings, such as railway stations, industrial halls, etc. However, the visual aspects form and architecture - play an important role as concerns prisons built in the late nineteenth century, in which well-known architects have been involved. They partly reflect an improved procedure in terms of heritage management, whereby much weight is put on architectural history, but are also a symptom of the self-evident role that aesthetics has gained in post-modernity. An urgent question is whether this is a case of a conscious or unconscious imposition of silence around the problematic parts of prison history if it is the building's form and architecture that set the terms. The first three mediating techniques that signify the cultural institutions' place in the urban setting - distancing, instrumentalisation, and narrative styling - are all used to strengthen certain messages. When Jay Winter (2010: 4) emphasised that silence is about'a socially 
constructed silence', he underlined that it can be a result of a conscious strategy, in which several considerations have played a role. It can be used to hide and protect actors and individuals who have played a part in this history, as well as their relatives, from exposure and recognition; such ethical considerations have to be weighed against the gains that the new historical knowledge provides. Yet, we may also wonder if it is a result of a conscious exclusion of elements of history that do not sell very well if a building is used in branding efforts to revitalise towns. The technique of distancing presented earlier prescribes the exact amount of 'spice' and 'taste' to stimulate the senses, but that is where it stops. Nobody enjoys a meal, however tasty, if it is accompanied by the smell of sweat, fear, dirt and defecation that permeated nineteenth-century prisons. We are, in other words, in danger of 'domesticising' history (White 2003). Selection can be a result of a clearly controlled and conscious direction motivated by the possibility of selling cultural heritage as an attractive product on a competitive and exposed market. This was well illustrated by Lowenthal's work on nostalgia (1985) and Hewison's critical approaches to the consequences of the boom in the 'heritage industry' (1987). It can be interpreted as a strategy that succeeds in making 'difficult heritage' (Logan \& Reeves 2009) more digestible by wrapping it up nicely. Then only certain aspects of a building's history are relevant, aspects that share characteristics with memory, as Assmann (2010: 43) describes it: "A memory that is intentionally and symbolically constructed is based on acts of selection and exclusion, neatly separating useful from not useful, relevant from irrelevant memories". The authorities in urban municipalities often regard culture as a relevant means to promote their profile and image, and share the opinion that various monumental buildings - for instance old prisons - have potential in terms of urban regeneration projects. Consequently, cultural heritage is constructed, "show-cased and turned into commercial products that are integrated into the fabric of central public spaces" (Mordue 2010: 172ff.).

\section{CONCLUSION}

The study of prisons as heritage has political implications. This is the case regardless of whether they are interpreted as memorials to crimes against the nation or minority groups (see, for instance, Deacon 2004), or as penal institutions, such as the two cases in this study. There is a difference between the histories that we as a nation are proud to portray and those of which we are ashamed. As the article has shown, this is also reflected in the particular material structures we want to classify as heritage. Examination of the messages derived from the studied prisons has revealed that, although their social 
history and the painful memories in which they are steeped are not necessarily consciously under-communicated, they play only a minor role. What the visitors see is a too sanitised, commercially driven presentation of the inside of old prisons. These re-imagined sites occlude the voices of the people that once constituted the living element of the biographies of these buildings.

The prisons described in the article portray some of the most symbolic elements of prison architecture. The architecture is used as 'set pieces' for new performances; for example, an exciting backdrop to a restaurant or a setting for concerts or art exhibitions. There are several other former prisons in the country that serve the same purposes (Stavanger, Halden, Drøbak, Molde, Smedvigen i Kabelvåg). Even if they do not necessarily stress the building's original function to any considerable degree, they have succeeded in keeping their original architectural form intact, and the naming of new functions or activities in accordance with the building's former use as a penal institution means that parts of the history - and primarily architectural history - are kept alive. The considerable potential of such buildings to write new chapters of social and cultural history is still waiting to be tapped, however. At present, the stark social reality of imprisonment is more digestible when wrapped up and disguised.

\section{ACKNOWLEDGEMENTS}

The article is part of a larger strategic research project 'Cultural heritage: Negotiations, politics and practice' initiated by the Norwegian Institute for Cultural Heritage Research and funded by the Research Council of Norway. I thank the editors and the two anonymous reviewers for their valuable comments.

\section{ABBREVIATIONS}

NIKU - Norsk institutt for kulturminneforskning (Norwegian Institute for Cultural Heritage Research)

\section{REFERENCES}

Al-Hosany, Nawal \& Elkadi, Hisham 2002. Sustainability Approaches for Incarceration Architecture. Renewable \& Sustainable Energy Reviews, Vol. 6, No. 5, pp. 457-470. http://dx.doi.org/10.1016/S1364-0321(01)00013-2. 
Ashworth, Gregory \& Hartmann, Rudi 2005. Horror and Human Tragedy Revisited: The Management of Sites of Atrocities for Tourism. New York: Cognizant Communication Corporation.

Assmann, Aleida 2010. Re-Framing Memory: Between Individual and Collective Forms of Constructing the Past. In: K. Tilmans \& F. Van Vree \& J. Winter (eds.) Performing the Past. Memory, History, and Identity in Modern Europe. Amsterdam: Amsterdam University Press, pp. 35-50.

Benton, Tim \& Cecil, Clementine 2010. Heritage and Public Memory. In: T. Benton (ed.) Understanding Heritage and Memory. Manchester: Manchester University Press, pp. 7-43.

Brand, Stewart 1994. How Buildings Learn: What Happens after They're Built. London: Phoenix Illustrated.

Council of Europe 2008 = Heritage and Beyond. Strasbourg: Council of Europe Publishing. Available at http://www.coe.int/t/dg4/cultureheritage/heritage/identities/ PatrimoineBD_en.pdf, last accessed on March 5, 2014.

Deacon, Harriet 2004. Intangible Heritage in Conservation Management Planning: The Case of Robben Island. International Journal of Heritage Studies, Vol. 10, No. 3, July, 2004, pp. 309-319. http://dx.doi.org/10.1080/1352725042000234479.

DeSilvey, Caitlin 2010. Memory in Motion: Soundings from Milltown, Montana. Social \& Cultural Geography, Vol. 11, No. 5, pp. 491-510. http://dx.doi.org/10.1080/14 649365.2010.488750.

Drange, Sverre 2001. Hus og historie i Hønefoss. [Houses and History in Hønefoss.] Hønefoss: Eikli Grafisk.

Edginton, Barry 1997. Moral Architecture: The Influence of the York Retreat on Asylum Design. Health \& Place, Vol. 3, No. 2, pp. 91-99. http://dx.doi.org/10.1016/S13538292(97)00003-8.

Evans, Graeme 2009. Creative Cities, Creative Spaces and Urban Policy. Urban Studies, Vol. 46, No. 5-6, pp. 1003-1040. http://dx.doi.org/10.1177/0042098009103853.

Fenka 2008. Huset $i$ Tordenskjolds gate; «Fenka» og Brannstasjonen Kirkegata 66A og $B$. Levanger: Skriftserie No. 5. [Minutes available at the local history archive at Levanger library.]

Flynn, M. K. 2011. Decision-Making and Contested Heritage in Northern Ireland: The Former Maze Prison/Long Kesh. Irish Political Studies, Vol. 26, No. 3, pp. 383401. http://dx.doi.org/10.1080/07907184.2011.593741.

Foucault, Michel 1991 [1977]. Discipline and Punish: The Birth of the Prison. Harmondsworth: Penguin.

Freestone, Robert \& Gibson, Chris 2006. The Cultural Dimension of Urban Planning Strategies: An Historical Perspective. In: J. Monclus \& M. Guardia (eds.) Culture, Urbanism and Planning. Aldershot: Ashgate, pp. 21-43. Available at ftp://ftparch. emu.edu.tr/Courses/arch/Arch651/books/books/Culture_Urbanism\%20and\%20 planning.pdf, last accessed on March 5, 2014.

Gregory, Derek 1994. Geographical Imaginations. Cambridge, MA: Blackwell Publishers. Graham, Brian \& Ashworth, Greg J. \& Tunbridge, John E. 2000. A Geography of Heritage: Power, Culture and Economy. London: Arnold.

Hamran, Ruth 1962. Heinrich Ernst Schirmer og hans plass i norsk arkitekturhistorie. [Heinrich Ernst Schirmer and His Place in Norwegian Architectural History.] 
In: Fortidsminneforeningens årbok, 117 årgang, pp. 43-84. Oslo: Fortidsminneforeningen.

Hewison, Robert 1987. The Heritage Industry: Britain in a Climate of Decline. London: Methuen.

Kirschenblatt-Gimblett, Barbara 2012 [2010]. From Ethnology to Heritage: The Role of the Museum. In: Bettina Messias Carbonell (ed.) Museum Studies. An Anthology of Contexts. Second edition. Chichester: Wiley-Blackwell, pp. 199-205.

Kjus, Audun 2010. Justissektorens værelser. Landsverneplan for justissektoren: Historiedel.

[National Preservation Plan for the Legal Sector: History Presentation.] 4. Mars 2010. Oslo. Available at http://www.regjeringen.no/upload/JD/Vedlegg/Hoeringer/ Justissektorens_vaerelser.pdf, last accessed on March 6, 2014.

Kopytoff, Igor 1986. The Cultural Biography of Things: Commoditization as Process. In: A. Appadurai (ed.) The Social Life of Things: Commodities in Cultural Perspective. Cambridge: Cambridge University Press, pp. 64-91.

Lefebvre, Henri 1991 [1974 in French]. The Production of Space. Translated by Donald Nicholson-Smith. Oxford: Blackwell.

Levanger Historielag $2011=\AA$ Arbok for Levanger Historielag. [The Historic Society of Levanger's Yearbook 2011.] Levanger.

Logan, William \& Reeves, Keir (eds.) 2009. Places of Pain and Shame: Dealing with "Difficult Heritage". London: Routledge.

Lowenthal, David 1985. The Past Is a Foreign Country. Cambridge: Cambridge University Press.

Macdonald, Sharon 2009. Unsettling Memories: Intervention and Controversy over Difficult Public Heritage. In: M. Anico \& E. Peralta (eds.) Heritage and Identity. Engagement and Demission in Contemporary World. London: Routledge, pp. 93-104.

Markus, Thomas A. 1993. Buildings and Power: Freedom and Control in the Origin of Modern Building Types. London \& New York: Routledge.

Meld. St. 35 (2012-2013). Framtid med fotfeste: Kulturminnepolitikken. [White Paper about Future Cultural Heritage Policy.] Oslo: Miljøverndepartementet. Available at http:// www.regjeringen.no/pages/38311590/PDFS/STM201220130035000DDDPDFS. pdf, last accessed on March 6, 2014.

Mordue, Tom 2010. Time Machines and Space Craft: Navigating the Spaces of Heritage Tourism Performance. In: E. Waterton \& S. Watson (eds.) Culture, Heritage and Representation. Perspectives on Visuality and the Past. Aldershot: Ashgate, pp. 173-194.

Pink, Sarah 2009. Doing Sensory Ethnography. London: SAGE.

Rose, Gillian 2007 [2001]. Visual Methodologies: An Introduction to the Interpretation of Visual Materials. Second edition. London: SAGE.

Rosenthal, Michael 2008. London versus Sydney, 1815-1823: The Politics of Colonial Architecture. Journal of Historical Geography, Vol. 34, No. 2, pp. 191-219. http:// dx.doi.org/10.1016/j.jhg.2007.07.001.

Schacter, Daniel L. (ed.) 1995. Memory Distortion: How Minds, Brains, and Societies Reconstruct the Past. Cambridge, MA: Harvard University Press.

Schirmer, Heinrich E. \& von Hanno, Wilhelm 1859. Planer over fengselsbygninger. Til det Kgl. Norske Justitis-Departement. Beskrivelse af Fængselsbygningerne. Beregninger over Omkostningerne ved Opførelsen af de på vedlagte Tegninger 
fremstillede Fængselsbygninger. [Plans for Prison Buildings. Description of the Prison Buildings and Calculation of Expenses Involved in the Building Activities.] Christiania.

Schudson, Michael 1995. Dynamics of Distortion in Collective Memory. In: D.L. Schacter (ed.) Memory Distortion: How Minds, Brains, and Societies Reconstruct the Past. Cambridge, MA: Harvard University Press, pp. 346-364.

Stone, Philip \& Sharpley, Richard 2008. Consuming Dark Tourism: A Thanatological Perspective. Annals of Tourism Research, Vol. 35, No. 2, pp. 574-595. http:// dx.doi.org/10.1016/j.annals.2008.02.003.

Strange, Carolyn \& Kempa, Michael 2003. Shades of Dark Tourism: Alcatraz and Robben Island. Annals of Tourism Research, Vol. 30, No. 2, pp. 386-405.

Sturken, Marita \& Cartwright, Lisa 2009 [2001]. Practices of Looking: An Introduction to Visual Culture. New York \& Oxford: Oxford University Press.

Swensen, Grete 1997. Moderne, men avleggs: Foreningers byggevirksomhet $i$ formativt perspektiv 1870 - 1940. [Modern Yet Obsolete? Volunteer Organisations' Building of Community Halls in a Formative Perspective 1870-1940.] Doktoravhandling i etnologi, Institutt for kulturstudier. Acta Humaniora 26. Universitetet i Oslo. Oslo: Universitetsforlaget.

Swensen, Grete 2012. Concealment or Spectacularisation: Analysing the Heritagisation Process of Old Prisons. In: C. Clark \& C.A. Brebbia. Defence Sites: Heritage and Future. WIT Transactions on the Built Environment, Vol. 123, pp. 231-243. http://dx.doi.org/10.2495/DSHF120191.

Swensen, Grete 2013. Fakta, fortielse eller fordreining: Når fengsler omgjøres til kulturarv. [Facts, Concealment or Distortion: When Prisons are Transformed into Cultural Heritage.] In: G. Swensen (ed.) A lage kulturminner - hvordan kulturarv forstås, formes og forvaltes. [To Make Cultural Heritage: How Cultural Heritage Is Interpreted, Constructed and Managed.] Oslo: Novus Forlag, pp. 179-204.

Taylor, Brandon 1994. From Penitentiary to "Temple of Art": Early Metaphors of Improvement at the Millbank Tate. In: M. Pointon (ed.) Art Apart: Art Institutions and Ideology across England and North America. Manchester \& New York: Manchester University Press, pp. 9-32.

Throsby, David 2001. Economics and Culture. Cambridge: Cambridge University Press.

Tomlinson, Heather 1984. Design and Reform: The 'Separate System' in the NineteenthCentury English Prison. In: A.D. King (ed.) Buildings \& Society: Essays on the Social Development of the Built Environment. London: Routledge \& Kegan Paul, pp. 51-66.

Tunbridge, John E. \& Ashworth, Gregory J. 1996. Dissonant Heritage: The Management of the Past as a Resource in Conflict. Chichester: Wiley.

Urry, John 1990. The Tourist Gaze. Leisure and Travel in Contemporary Societies. London \& Thousand Oaks, CA \& New Delhi: Sage Publications.

White, Hayden 2003. Historie og fortelling. Utvalgte essay. Utvalg og innledning ved Heidi Nordland. [History and Narratives. Selected Essays. Selection and Introduction by Heidi Nordland.] Oslo: Pax Forlag.

Williams, Paul 2007. Memorial Museums: The Global Rush to Commemorate Atrocities. Oxford: Berg.

Winter, Jay 2010. Thinking about Silence. In: Efrat Ben-Ze'ev \& Ruth Ginio \& Jay Winter (eds.) Shadows of War: A Social History of Silence in the Twentieth Century. Cambridge: Cambridge University Press, pp. 3-31. 